\title{
Fluoride in Thermal Spring Water and in Plants of Nevada and Its Relationship to Fluorosis in Animals
}

\author{
JOE KUBOTA, E.A. NAPHAN, AND G.H. OBERLY
}

\begin{abstract}
Fluoride concentrations in water from selected thermal springs and in plants were determined to evaluate their role as sources of $F^{-}$ for grazing animals in Nevada. The $F^{-}$concentration in water varied with thermal spring sources and ranged from about 2 to 17 ppm. F concentration in plants ranged from about 0.1 to over 220 ppm, depending upon species of plants and the soil on which the plants were grown. The $F^{-}$concentration in plants from any given thermal spring location was not uniformly high, but together with $F^{-}$concentration of the water, appears to contribute to possible cases of fuorosis in cattle. Although small area-wise the spring waters and the area they flow over are important to grazing animals, because they provide drinking water and have lush forage.

It is well known that excess fluoride (F) causes fluorosis in grazing animals and reduced fruit production (NAS 1971). Most of the known problem areas are downwind of smelter plants and steel mills. The severity of symptoms in grazing animals with increasing $F^{-}$levels in feed has been outlined (NAS 1971). A level of $50 \mathrm{ppm}$ or more of $F$ in feed plants has been recognized to cause fluorosis in grazing animals (NAS 1971). Fluorosis in animals grazed in naturally occurring areas is less well defined, although thermal springs, volcanic emanations, and volcanic ash are natural sources of $F$ (Goldschmidt 1954). We undertook a study in Nevada, where as many as 300 thermal springs occur (Garside 1974), to establish how $F^{-}$in the water affects $\mathbf{F}^{-}$concentration in plants grown on soils drained by the water, and how $F$ from both sources contributes to $F^{-}$intake of the animal eating the plants. We present the results of our study.
\end{abstract}

\section{Plan of Study}

Ten locations with thermal springs were selected (Fig. 1). Included among these was the Evans Creek Warm Springs (location VI), where fluorosis had been earlier diagnosed in cattle grazed in the area (Personal Communication; W. Binns, DVM; SEA, FN, USDA, ret.).

At each location, our study focused on the wet vegetated site nearest to the hot springs. We collected samples here and from the wet sites downstream. We also collected samples from adjacent dry soil sites nearby to observe effects of limiting soil moisture on plant $\mathrm{F}^{-}$concentration.

Duplicate samples of water were taken in the summer of 1977 from hot springs and from cisterns, ditches, and canals. The water sa mples were collected in $250-\mathrm{ml}$ acid-rinsed polyethylene bottles. They were shipped by air to Ithaca, N.Y., and kept refrigerated until they were analyzed. The $F^{-}$concentration was determined

\footnotetext{
Authors are research soil scientist, NETSC, SCS, U.S. Plant, Soil and Nutrition Laboratory, and professor, Department of Agronomy, Cornell University, Ithaca. N.Y. 14853; state soil scientist, SCS, Reno, Nevada; and associa te professor, Promology Department, Cornell University.

The authors gratefully acknowledge the help they received from E.E. Cary, U.S. Plant, Soil and Nutrition Laboratory, in the analysis of the samples.

Manuscript received July 6,1980
}

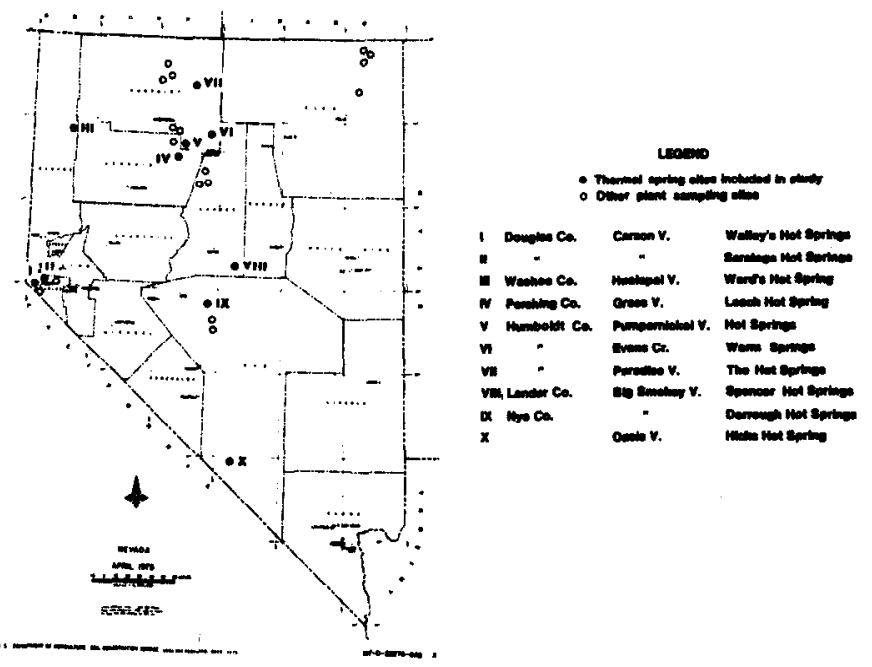

Fig. 1. Location of sites in Nevada selected for study.

within 3 weeks of time of sampling. Some characteristics of the water are summarized in Table 1 .

Plant samples were collected by species at the same time to determine species differences in $\mathrm{F}^{-}$absorption. Grasses were sampled from most of the sites. Current growth of leaves and stems of desert shrubs such as greasewood and big sagebrush was sampled from a number of dry and wet sites, but rushes and sedges were available only on the wet soil sites. The samples were air dried at field locations, oven dried $\left(50^{\circ} \mathrm{C}\right)$ in Ithaca, and ground in a Wiley mill. Leaves of desert shrubs were hand separated from stems before grinding.

Samples of surface soil horizons were taken at most sites after the soils were classified. After air-drying, the samples were coarse ground to pass a 2-mm sieve. Portions of these samples (about 30 g), ground further to pass a 200-mesh nylon screen, were used for analyses.

Since $\mathrm{F}^{-}$is a common constituent in phosphatic rocks (Hill 1964), we also collected samples of plants growing on reclaimed phosphate mine overburden in southwestern Wyoming. Plants from range sites nearby and reclaimed strip mine (coal) were sampled for comparative purposes.

Fluoride concentration was determined by a specific ion electrode (Levaggi et al. 1971). The $F^{-}$in water was determined after mixing the sample with an equal volume of a buffer (total ionic strength activity buffer, pH 5.2). Plant samples were burned in a Schoeniger flask and purged with $\mathrm{O}_{2}$, and the $\mathrm{F}^{-}$was captured in $0.05 \mathrm{~N} \mathrm{KOH}$. Water soluble $\mathrm{F}^{-}$and $\mathrm{KOH}$ - extractable $\mathrm{F}^{-}$were determined on selected soil samples using a $1: 10$ soil-liquid extract. The suspension was shaken for one-half hour and centrifuged; an aliquot of the supernatant liquid was taken and made to a volume 
Table 1. Chemical characteristics of water samples in relation to their source.

\begin{tabular}{|c|c|c|c|c|c|c|}
\hline Sample source & pH & $\mathrm{F}^{-}$ & $\mathrm{Ca}$ & $\mathbf{M g}$ & $\mathbf{K}$ & $\mathrm{Na}$ \\
\hline $\begin{array}{l}\text { I. Cistern from spring } \\
\text { Drainage canalı }\end{array}$ & $\begin{array}{l}8.4 \\
7.4\end{array}$ & $\begin{array}{l}3.42 \\
1.94\end{array}$ & $\begin{array}{r}9.4 \\
19.5\end{array}$ & $\begin{array}{l}0.15 \\
5.9\end{array}$ & $\begin{array}{r}4.2 \\
18.2\end{array}$ & 29.1 \\
\hline $\begin{array}{l}\text { 11. Spring } \\
\text { Drainage ditch }\end{array}$ & $\begin{array}{l}8.2 \\
8.2\end{array}$ & $\begin{array}{l}2.33 \\
2.39\end{array}$ & $\begin{array}{l}136.3 \\
141.7\end{array}$ & $\begin{array}{l}0.09 \\
0.08\end{array}$ & $\begin{array}{l}4.7 \\
4.5\end{array}$ & $\begin{array}{l}34.1 \\
35.5\end{array}$ \\
\hline $\begin{array}{l}\text { III. Spring } \\
\text { Pond }\end{array}$ & $\begin{array}{l}7.7 \\
7.5\end{array}$ & $\begin{array}{l}5.70 \\
6.00\end{array}$ & $\begin{array}{l}17.0 \\
28.0\end{array}$ & $\begin{array}{l}4.59 \\
5.09\end{array}$ & $\begin{array}{r}19.3 \\
21.3\end{array}$ & $\begin{array}{r}74.8 \\
81.6\end{array}$ \\
\hline $\begin{array}{l}\text { IV. Spring } \\
\text { Cistern }\end{array}$ & $\begin{array}{l}7.8 \\
7.8\end{array}$ & $\begin{array}{l}7.22 \\
6.00\end{array}$ & $\begin{array}{l}7.9 \\
4.1\end{array}$ & $\begin{array}{l}0.25 \\
1.09\end{array}$ & $\begin{array}{l}12.7 \\
13.7\end{array}$ & $\begin{array}{l}38.7 \\
37.3\end{array}$ \\
\hline $\begin{array}{l}\text { V. Spring (a) } \\
\text { Spring (b) }\end{array}$ & $\begin{array}{l}8.7 \\
8.7\end{array}$ & $\begin{array}{l}8.55 \\
9.50\end{array}$ & $\begin{array}{r}16.1 \\
2.1\end{array}$ & $\begin{array}{l}3.4 \\
1.6\end{array}$ & $\begin{array}{l}22.0 \\
23.3\end{array}$ & $\begin{array}{l}45.1 \\
53.9\end{array}$ \\
\hline $\begin{array}{l}\text { VI. Spring (warm) } \\
\text { Drainage ditch }\end{array}$ & $\begin{array}{l}7.6 \\
7.7\end{array}$ & $\begin{array}{l}3.46 \\
4.56\end{array}$ & $\begin{array}{l}18.5 \\
17.2\end{array}$ & $\begin{array}{l}4.2 \\
3.4\end{array}$ & $\begin{array}{l}4.8 \\
5.2\end{array}$ & $\begin{array}{l}13.2 \\
14.5\end{array}$ \\
\hline $\begin{array}{l}\text { VII. Spring } \\
\text { Little Humboldt R.I }\end{array}$ & $\begin{array}{l}7.2 \\
7.6\end{array}$ & $\begin{array}{l}4.56 \\
0.62\end{array}$ & $\begin{array}{l}14.6 \\
25.3\end{array}$ & $\begin{array}{l}7.7 \\
6.1\end{array}$ & $\begin{array}{r}15.5 \\
8.8\end{array}$ & $\begin{array}{l}65.9 \\
11.1\end{array}$ \\
\hline $\begin{array}{l}\text { VIII. Spring } \\
\text { Spring, water tap }\end{array}$ & - & $\begin{array}{l}3.74 \\
3.80\end{array}$ & $\begin{array}{l}21.9 \\
25.1\end{array}$ & $\begin{array}{l}8.9 \\
8.8\end{array}$ & $\begin{array}{l}36.8 \\
36.7\end{array}$ & $\begin{array}{l}42.5 \\
40.6\end{array}$ \\
\hline $\begin{array}{l}\text { Spring } \\
\text { IX. Spring, water tap } \\
\text { Drainage ditch }\end{array}$ & $\begin{array}{l}8.5 \\
8.6 \\
7.9\end{array}$ & $\begin{array}{l}13.08 \\
12.92 \\
17.29\end{array}$ & $\begin{array}{l}1.3 \\
1.4 \\
9.1\end{array}$ & $\begin{array}{l}0.12 \\
0.10 \\
1.9\end{array}$ & $\begin{array}{l}3.6 \\
4.3 \\
5.3\end{array}$ & $\begin{array}{l}22.5 \\
22.8 \\
27.8\end{array}$ \\
\hline X. Spring ${ }^{3}$ & 7.0 & 2.2 & 25.3 & 4.8 & 9.3 & - \\
\hline
\end{tabular}

Water is from mixed sources including water from springs.

2A separate well water source for domestic use had the following composition (ppm)-

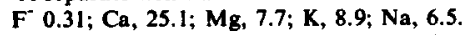

${ }^{3}$ A separate well water source for domestic use had the following composition (ppm)$\mathrm{F}^{-}, 0.51 ; \mathrm{Ca}, 14.9 ; \mathrm{Mg}, 0.6 ; \mathrm{K}, 7.7$.

of $20 \mathrm{ml}$ with the $\mathrm{pH} 5.2$ buffer.

Elements other than $\mathrm{F}^{-}$were determined by established procedures of the Ithaca Laboratory.

\section{Factors That Affect Plant $\mathrm{F}^{-}$Concentrations}

\section{Plant Species}

A summary of $F^{-}$concentration by broad groups of plants is presented in Table 2 . The range of $F^{-}$concentration was widest in rush, a recognized $F$ accumulator plant (NAS 1971). Fluoride concentration was uniformly low in stems of desert shrubs and the differences were small between leaves and stems (Table 3).

\section{Soil-water-plant Relationships}

The median $F^{-}$concentration in grasses (Table 4) from the wet soils $(3.6 \mathrm{ppm})$ and from the dry soils $(1.3 \mathrm{ppm})$ was nearly the same, but the concentration range was wider for plants for the wet soils $(0.3$ to $69.8 \mathrm{ppm})$. Since the species growing on the dry and the wet soil sites were different, our results do not exclude the possibility that some species of grasses growing on the dry soil sites would not have more $F^{-}$if they were grown on the wet soil sites.

Larger differences in $\mathrm{F}^{-}$concentration were found in plants between two groups of wet soils: (a) those draining water from thermal springs, and (b) those draining nonthermal spring water.

Table 2. F $^{-}$concentration by broad plant groups of Nevada.

\begin{tabular}{lccl}
\hline & & \multicolumn{2}{c}{$\mathrm{F}^{-}$concentration (ppm) } \\
\cline { 3 - 4 } Group of plants & No. samples & Median & Range \\
\hline Grasses & 116 & 2.3 & 0.1 to 69.8 \\
Sedge & 12 & 7.0 & 0.4 to 42.3 \\
Rushes & 33 & 4.7 & 0.2 to 224 \\
Desert shrubs- & & & \\
$\quad$-leaves & 81 & 1.3 & 0.1 to 11.8 \\
\multicolumn{1}{c}{- -stems } & 74 & 1.1 & 0.4 to 6.9 \\
\hline
\end{tabular}

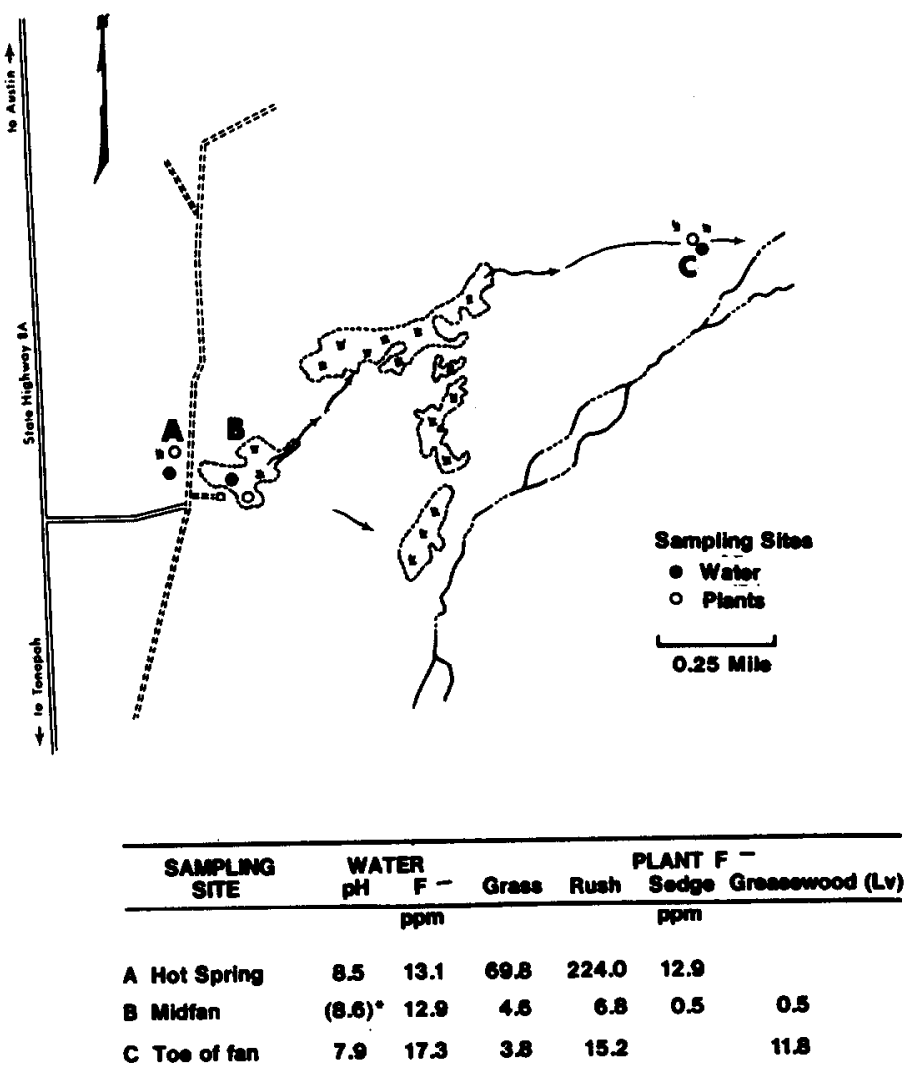

Water from tap fed from hot epring

Fig. 2. Changes in $F$ concentration in plants grown downslope from a thermal spring.

The median $\mathrm{F}^{-}$concentration in grasses from areas draining thermal spring water was $6.08 \mathrm{ppm}$, and in grasses from the nonthermal areas, $0.91 \mathrm{ppm}$. Similarly, the median concentration in rush from areas draining thermal spring water was $5.7 \mathrm{ppm}$, and $0.62 \mathrm{ppm}$ in rush from areas draining nonthermal water. The range of $\mathrm{F}^{-}$concentrations in grasses (0.41 to $2.2 \mathrm{ppm})$ and rush (0.41 to $3.2 \mathrm{ppm})$ from areas draining nonthermal water was narrow.

A pattern of decreasing $\mathrm{F}^{-}$concentration in plants downslope from the spring to the toe of an alluvial fan is presented in Figure 2. The flow of water downslope here (location IX, Fig. 1) follows a natural drainageway. Grasses and rush growing at the source of the

Table 3. Summary of $F^{-}$concentration in leaves and stems (current season growth) of desert shrubs.

\begin{tabular}{lccc}
\hline \hline & & \multicolumn{2}{c}{ F concentration (ppm) } \\
\cline { 4 - 4 } Species' and plant part & No. samples & Median & Range \\
\hline Leaves & 28 & 1.8 & $0.1-9.9$ \\
Big sagebrush & 1 & 1.0 & -- \\
Bitterbrush & 27 & 2.1 & $0.2-11.8$ \\
Black greasewood & 15 & 1.1 & $0.6-2.4$ \\
Rabbitbrush & 10 & 0.9 & $0.4-3.0$ \\
Shadscale & & & \\
Stems & 27 & 1.8 & $0.5-4.2$ \\
Big sagebrush & 1 & 1.0 & - \\
Bitterbrush & 21 & 0.7 & $0.4-6.9$ \\
Blackgreasewood & 15 & 1.1 & $0.7-1.6$ \\
Rabbitbrush & 10 & 1.2 & $0.4-3.0$ \\
Shadscale & & & \\
\hline
\end{tabular}

'Big sagebrush-(Artemesia tridentata); bitterbrush-(Purshia rridentata); black greasewood-(Sarcobatus vermiculatus); rubber rabbitbrush-(Chysothamnus nauseosus); shadscale-(Atriplex contertifolia) 
Table 4. Summary of $\mathrm{F}^{-}$concentration in arid region grasses.

\begin{tabular}{|c|c|c|c|}
\hline \multirow[b]{2}{*}{ Species of grasses } & \multirow{2}{*}{$\begin{array}{l}\text { No. } \\
\text { samples }\end{array}$} & \multicolumn{2}{|c|}{$\mathrm{F}^{-}$concentration } \\
\hline & & Median & Range \\
\hline \multicolumn{4}{|l|}{ Grasses dominantly from dry soil sites } \\
\hline $\begin{array}{l}\text { Bluebunch wheatgrass-(Agropyron } \\
\text { spicatum) }\end{array}$ & 3 & 1.3 & $0.7-1.4$ \\
\hline $\begin{array}{l}\text { Cheatgrass-(Bromus tectorum) } \\
\text { Crested wheatgrass-(Agropyron }\end{array}$ & 6 & 2.4 & $0.9-4.2$ \\
\hline cristatum) & 11 & 1.3 & $0.1-5.3$ \\
\hline $\begin{array}{l}\text { Creeping wildrye-(Elymus triticoides) } \\
\text { Indian ricegrass-(Oryzopsis }\end{array}$ & 3 & 1.0 & $0.4-1.1$ \\
\hline hymenoides) & 8 & 1.5 & $0.8-4.8$ \\
\hline $\begin{array}{l}\text { Intermediate wheatgrass-(Agropyron } \\
\text { intermedium) }\end{array}$ & 4 & 1.4 & $1.1-2.0$ \\
\hline $\begin{array}{l}\text { Streambank wheatgrass-(Agropyron } \\
\text { riparium) } \\
\text { Western wheatgrass-(Agropyron }\end{array}$ & 3 & 2.8 & $0.8-4.4$ \\
\hline smithii) & 5 & 1.4 & $0.7-2.7$ \\
\hline Other grasses (16 species) & 20 & 2.2 & $0.4-26.4$ \\
\hline Overall & 52 & 1.3 & $0.1-26.4$ \\
\hline \multicolumn{4}{|c|}{ Grasses dominantly from wet or irrigated soil sites } \\
\hline Alkali cordgrass-(Spartina gracilis) & 5 & 3.3 & $2.1-60.8$ \\
\hline Alta fescue-(Festuca arundinacea) & 6 & 1.3 & $1.0-13.4$ \\
\hline Basin wildrye-(Elymus cinerus) & 8 & 4.3 & $1.3-41.8$ \\
\hline Bermudagrass-(Cynodon sp.) & 4 & 2.1 & $0.6-11.8$ \\
\hline $\begin{array}{l}\text { Inland saltgrass-(Distichlis stricta) } \\
\text { Tall wheatgrass-(Agropyron }\end{array}$ & 28 & 6.6 & $0.3-69.8$ \\
\hline $\begin{array}{l}\text { Tall wheatgrass-(Agropyron } \\
\text { elongatum) }\end{array}$ & & & \\
\hline $\begin{array}{l}\text { elongatum) } \\
\text { Overall }\end{array}$ & 64 & $\begin{array}{l}1.3 \\
3.6\end{array}$ & $\begin{array}{l}0.5-11.4 \\
0.3-69.8\end{array}$ \\
\hline All grasses & 116 & 2.3 & $0.1-69.8$ \\
\hline
\end{tabular}

spring (site A) had exceedingly large amounts of $\mathrm{F}^{-}$. Plant roots here are continually immersed in the flowing spring water. Soil effects are minimal because the water flows over travertine capped by thin detritus, mostly organic. On the downslope positions (sites $B$ and $C$ ), plants had appreciably less $F^{-}$, although the water at site $\mathrm{C}$ had more $\mathrm{F}^{-}$at site $\mathrm{C}$ than at site $\mathrm{A}$. Such differences in plant concentration suggest that $\mathrm{F}^{-}$is fixed in soils and is less available to plants.

The $\mathrm{F}^{-}$concentration in plants growing in an area (Location Vl, Fig. 1) where spring water is redistributed through improved irrigation is presented in Figure 3. The area affected by high $\mathrm{F}^{-}$is enlarged although the plants do not have uniformly high $\mathrm{F}^{-}$concentration. The $\mathbf{F}^{-}$in the plants together with that in the water undoubtedly contributes to incidence of fluorosis in cattle here.

Changes in $\mathrm{F}^{-}$concentrations in plants were not consistently associated with corresponding increases or decreases in $B, M o$, and $\mathrm{Se}$, (Table 5) or in $\mathrm{Ca}, \mathrm{K}$, and Na. Molybdenosis (Mo-induced $\mathrm{Cu}$ deficiency) is an endemic nutritional problem in some wet meadows in Nevada (Kubota et al. 1961), but Mo is not a complicating

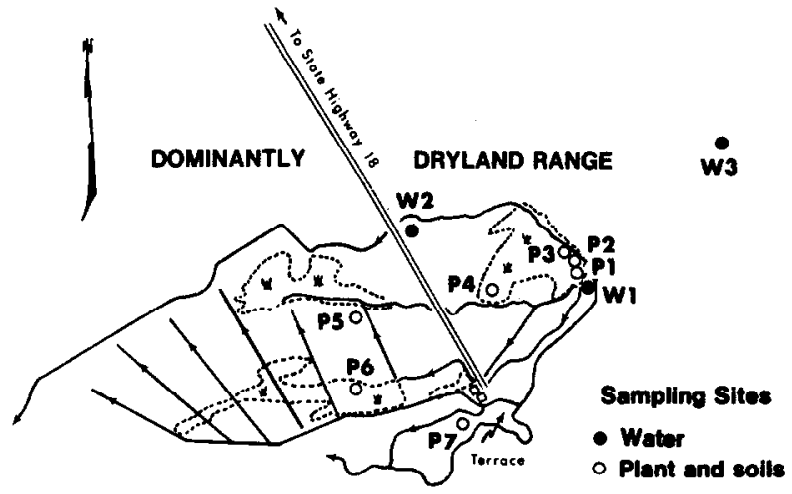

\begin{tabular}{|c|c|c|c|c|c|c|c|}
\hline \multirow{3}{*}{ Source Water } & \multirow{3}{*}{\multicolumn{2}{|c|}{$2+$}} & & \multicolumn{2}{|c|}{1 Mils } \\
\hline & & & & Soil & & & $. F-$ \\
\hline & & & Drainage & Site & $\mathrm{pH}$ & Grass & Aush \\
\hline & \multicolumn{3}{|c|}{ ppm } & & & \multicolumn{2}{|c|}{ ppm } \\
\hline \multirow[t]{2}{*}{ W1 Spring } & 7.6 & 3.5 & Poorly drained & P1 & 8.8 & 42.8 & 15.2 \\
\hline & & & & P2 & 8.9 & 44.3 & 108.6 \\
\hline \multirow[t]{2}{*}{ W2 Irrigation ditch } & 7.7 & 4.6 & & P3 & 8.8 & 8.9 & 12.2 \\
\hline & & & & P4 & 8.8 & 2.3 & 12.2 \\
\hline \multirow{4}{*}{$\begin{array}{l}\text { W3 Well water - } \\
\text { domestic }\end{array}$} & 7.6 & 0.3 & & P5 & 8.4 & 8.9 & 19.0 \\
\hline & & & & P6 & 9.8 & 20.6 & 37.3 \\
\hline & & & Woll drained & P7: & 7.0 & 8.4 & \\
\hline & & & & P8+ & & 4.9 & \\
\hline
\end{tabular}

- Irrigated field

+ Site on alluvial fan about 9 miles NE of ranch

Fig. 3. Fluoride concentration in plants in relation to the distribution of thermal springwater (warm) from improved irrigation.

factor here because the Mo concentrations in plants are low. Molybdenum concentrations of 10 to $20 \mathrm{ppm}$ or more in plants are associated with Mo-toxic areas for grazing animals in the U.S. (Kubota 1977). Concentrations of $\mathrm{Ca}, \mathrm{Mg}, \mathrm{Na}$, and $\mathrm{K}$ were in the normal range for the plant species of this general area as were $\mathrm{Cu}$ and $\mathrm{Zn}$.

Extractable soil $\mathrm{F}^{-}$was determined in three surface soil samples from the Hammond Ranch (Fig. 3) and those from Yerrington, Nevada. Soils of the Hammond Ranch had appreciably more $F^{-}$ than the other soils (Table 6) and the level of $F^{-}$extractable with water was in the range of $\mathrm{F}^{-}$reported for Sodic soils of India (Chhabra et al. 1980). The source of the soil $\mathrm{F}^{-}$, however, remains unclear. Here, irrigation water and volcanic ash both a re sources of soil $F^{-}$. In the Yerrington area, alluvium does not have an identifiable rock source of high $\mathrm{F}^{-}$. Exchangeable $\mathrm{Na}$ in the soils is reflected in the uniformly high soil $\mathrm{pH}$.

Table 5. Comparison of $\mathrm{F}^{-}, \mathrm{B}, \mathrm{Mo}$ and Se concentrations (ppm) in selected plants.

\begin{tabular}{|c|c|c|c|c|c|}
\hline \multirow[b]{2}{*}{ Sample } & \multirow[b]{2}{*}{ No. samples } & $\mathbf{F}^{-}$ & B & Mo & $\mathrm{Se}$ \\
\hline & & \multicolumn{4}{|c|}{ Mean $\mathbf{S E}^{\mathrm{t}}$} \\
\hline Legumes-Irrigated sites & 4 & $2.5 \pm 1.3$ & $66.5 \pm 21.6$ & $4.5 \pm 2.2$ & $0.07 \pm 0.02$ \\
\hline $\begin{array}{c}\text { Grasses-Wet soil sites } \\
\text { Dry soil sites }\end{array}$ & $\begin{array}{r}4 \\
13\end{array}$ & $\begin{array}{r}20.1 \pm 7.9 \\
6.9 \pm 4.5\end{array}$ & $\begin{array}{l}13.8 \pm 3.3 \\
16.0 \pm 3.2\end{array}$ & $\begin{array}{l}2.3 \pm 0.9 \\
2.7 \pm 0.9\end{array}$ & $\begin{array}{l}0.03 \pm 0.01 \\
0.85 \pm 0.37\end{array}$ \\
\hline Rushes & 4 & $32.6 \pm 24.9$ & $38.7 \pm 11.2$ & $2.7 \pm 1.3$ & $0.04 \pm 0.02$ \\
\hline $\begin{array}{l}\text { Desert shrubs } \\
\text { Leaves-Big sagebrush } \\
\text { Leaves-Rabbitbrush }\end{array}$ & $\begin{array}{l}6 \\
4\end{array}$ & $\begin{array}{l}1.8 \pm 0.41 \\
2.1 \pm 0.32\end{array}$ & $\begin{array}{l}48.3 \pm 2.9 \\
70.0 \pm 12.7\end{array}$ & $\begin{array}{l}1.3 \pm 0.4 \\
1.4 \pm 0.4\end{array}$ & $\begin{array}{l}0.36 \pm 0.20 \\
0.35 \pm 0.10\end{array}$ \\
\hline $\begin{array}{l}\text { Stems-Big sagebrush } \\
\text { Stems-Rabbitbrush }\end{array}$ & $\begin{array}{l}6 \\
4\end{array}$ & $\begin{array}{l}1.8 \pm 0.88 \\
1.2 \pm 0.22\end{array}$ & $\begin{array}{l}23.6 \pm 1.7 \\
44.4 \pm 14.1\end{array}$ & $\begin{array}{l}0.7 \pm 0.1 \\
0.8 \pm 0.2\end{array}$ & $\begin{array}{l}0.24 \pm 0.1 \\
0.25 \pm 0.1\end{array}$ \\
\hline
\end{tabular}

'Standard Error 
Table 6. Fluoride concentration in plants and $\mathrm{F}^{-}$extractable from soils on which the plants grew.

\begin{tabular}{|c|c|c|c|c|c|}
\hline \multirow[b]{2}{*}{ Source of sample } & \multicolumn{3}{|c|}{ Plant $\mathrm{F}^{-}$} & \multicolumn{2}{|c|}{ Extractable soil $\mathrm{F}^{-}(\mathrm{ppm})$} \\
\hline & Legumes & Grasses & Rushes & $\mathrm{H}_{2} \mathrm{O}$ & $\mathrm{KOH}$ \\
\hline $\begin{array}{l}\mathrm{LF}^{-} \text {area }{ }^{1} \\
\text { Aquic Calciorthid } \\
\text { Fluvaquentic Haploxerolls }\end{array}$ & $\begin{array}{r}0.6 \\
-\end{array}$ & $\begin{array}{l}0.5 \\
1.3\end{array}$ & - & $\begin{array}{l}1.7 \\
4.2\end{array}$ & $\begin{array}{l}2.6 \\
5.7\end{array}$ \\
\hline $\begin{array}{l}\text { High } F^{-} \text {area }^{2} \\
\text { Aquic Durorthids } \\
\text { Aquic Xerofluvents } \\
\text { Aquic Calciorthids }\end{array}$ & $\overline{4.9}$ & $\frac{44.2}{8.9}$ & $\begin{array}{r}106.6 \\
4.2 \\
19.0\end{array}$ & $\begin{array}{r}106.4 \\
87.4 \\
129.1\end{array}$ & $\begin{array}{r}91.2 \\
76.0 \\
102.6\end{array}$ \\
\hline
\end{tabular}

'Soils formed in mixed alluvium sampled near Yerrington, Nevada.

${ }^{2}$ Soils formed in mixed materials including volcanic ash and irrigated with $\mathrm{F}^{-}$rich thermal spring water.

\section{Reclaimed Mine Overburden}

In general, the $\mathrm{F}^{-}$concentrations were nearly the same in similar plants from phosphatic mine overburden, overburden from coal mining activities, and nearby rangeland (Table 7). The median $\mathrm{F}^{-}$ concentration in leaves of desert shrubs $(1.28 \mathrm{ppm})$ was the same as that given for leaves of desert shrubs of Nevada (Table 7), and grasses slightly lower. No consistent trends in $\mathrm{F}^{-}$concentration were evident with age of deposit. The older deposits were especially highly variable, occupying a series of ridges and mounds.

\section{General Discussion}

A study of selected thermal springs in Nevada indicated that some may be natural point sources of high $\mathrm{F}^{-}$. The pathway that $\mathrm{F}^{-}$ takes from thermal water sources to animals may be direct in drinking water or indirect through feed plants. Deterimental effects in animals drinking high $\mathrm{F}^{-}$thermal water would be expected to differ with levels of $\mathrm{F}^{-}$as well as with levels of cations, especially $\mathrm{Ca}$ and $\mathrm{Na}$. Fluoride activity in thermal water is reported to depend on CaF (Nordstrom and Jenne 1977). Differences in $\mathrm{F}^{-}$ activity might also be reasonably expected when $\mathrm{F}^{-}$in thermal water is applied to soils. Calcium fluoride may form in calcareous soils when high $\mathrm{F}^{-}$water is applied. The relatively low $\mathrm{F}^{-}$concentration in plants growing downslope at the Darrough site (Fig. 2) supports this view.

In plants growing immediately adjacent to active thermal springs (Site A, Fig. 2) $\mathrm{F}^{-}$concentrations may be due partly to evaporation of water vapor on leaf surface. Vapor deposition probably is not a major source of $F^{-}$in plants at the Evans Creek location (Fig. 3), because the flowing water is lukewarm and moisture vapor is minimal.

Soils of the high $\mathrm{F}^{-}$area clearly had more $\mathrm{F}^{-}$than soils of a low $F^{-}$area (Table 6), but it is evident from the data that a more intensive study is needed to relate soil $\mathrm{F}^{-}$concentrations to amounts found in the plants.

Observations at the Evans Creek location suggest that determination of $\mathrm{F}^{-}$in water may be important if thermal springs are under consideration for irrigation purposes. The redistribution of high $\mathrm{F}^{-}$ water from thermal springs could result in areas affected by high $\mathrm{F}^{-}$ water to be enlarged.

Soil areas that receive high $\mathrm{F}^{-}$water from thermal springs are relatively small but their impact on dietary $\mathrm{F}^{-}$of grazing animals may be substantial. The springs, where observed, are the principal source of water that animals drink in a generally water-deficient area and areas draining the springs support lush foragc. Rough estimates of $\mathrm{F}^{-}$intake by cattle grazed near two thermal springs were made, assuming daily intakes of $38 \mathrm{~L}$ ( 10 gallons) and feed intake of $9 \mathrm{~kg}$ ( 20 pounds) dry matter basis. These estimates show that cattle grazing in the Evans Creek area would have daily dietary intakes of about $400 \mathrm{mg}$ of $\mathrm{F}^{-}$while cattle grazing in the Darrough Hot Springs area would have about $900 \mathrm{mg}$. As with water, consideration of cations associated with $\mathrm{F}^{-}$in plants is necessary. The biological availability of the $\mathrm{F}^{-}$in feed plants to cattle is reported to be greater from $\mathrm{F}^{-}$associated with $\mathrm{Na}$ than $\mathrm{Ca}$ (summarized by Underwood 1971).

Levels of $50 \mathrm{ppm}$ or more of $\mathrm{F}^{-}$in feed plants have been suggested to be in the toxic range for cattle, an animal sensitive to excess $F^{-}$. In a rid regions where water is limited, determination of

Table 7. Fluoride concentration in plants grown on reclaimed mined land and adjacent range sites.

\begin{tabular}{|c|c|c|c|c|c|}
\hline \multirow[b]{2}{*}{ State } & \multirow{2}{*}{$\begin{array}{l}\text { Source of sample } \\
\text { (Geologic formation) }\end{array}$} & \multirow[b]{2}{*}{ Sampling site } & \multirow{2}{*}{ Grass } & \multicolumn{2}{|c|}{$\begin{array}{c}\mathrm{F}^{-} \text {concentration (ppm) } \\
\text { Desert shrubs }\end{array}$} \\
\hline & & & & Leaves & Stems \\
\hline Wyoming & Phosphoria & $\begin{array}{l}\text { Overburden - Phosphatic deposit } \\
\text { Rangeland } \\
\text { Overburden }\end{array}$ & $\begin{array}{l}1.08 \\
1.42\end{array}$ & $\begin{array}{l}2.30 \\
2.97\end{array}$ & $\begin{array}{l}2.38 \\
1.61\end{array}$ \\
\hline \multirow[t]{3}{*}{ Wyoming } & Hannah & $\begin{array}{l}\text { Overburden - Surface coal mining } \\
\text { Rangeland } \\
\text { Overburden } 21 / 2-\mathrm{yr} \text { old } \\
10-\mathrm{yr} \text { old } \\
30-\mathrm{yr} \text { old }\end{array}$ & $\begin{array}{l}4.75 \\
0.91 \\
0.87 \\
1.49\end{array}$ & $\begin{array}{l}3.07 \\
0.28 \\
1.00 \\
1.43\end{array}$ & $\begin{array}{l}1.77 \\
1.02 \\
0.89 \\
0.91\end{array}$ \\
\hline & Ferris & $\begin{array}{l}\text { Rangeland } \\
\text { Overburden } 21 / 2 \text {-yr old } \\
\qquad 30-y r \text { old }\end{array}$ & $\begin{array}{l}2.28 \\
1.63 \\
2.96\end{array}$ & $\frac{1.93}{0.91}$ & $\frac{1.45}{1.06}$ \\
\hline & Rock Springs & $\begin{array}{r}\text { Overburden 4-yr old } \\
25-y r \text { old }\end{array}$ & $\begin{array}{l}2.28 \\
1.25\end{array}$ & $\begin{array}{l}1.28 \\
2.13\end{array}$ & $\begin{array}{l}2.20 \\
1.41\end{array}$ \\
\hline Colorado & Mesa Verda & $\begin{array}{l}\text { Rangeland } \\
\text { Overburden } 21 / 2 \text {-yr old } \\
10-y r \text { old } \\
30-y r \text { old }\end{array}$ & $\begin{array}{l}0.38 \\
0.60 \\
0.64 \\
0.34\end{array}$ & $\begin{array}{l}0.49 \\
0.57 \\
0.64\end{array}$ & $\begin{array}{l}0.45 \\
- \\
0.48 \\
5.32\end{array}$ \\
\hline
\end{tabular}


$F^{-}$levels in drinking water scems equally important, especially if the water has a thermal spring source.

\section{References}

Chhabra, R., A. Singh, and I.P. Abrol. 1980. Fluorine in Sodic soils. Soil Sci. Soc. Amer. J. 44:33-36.

Garside, L.J. 1974. Geothermal exploration and development in Nevada through 1973. Nevada Bureau Mines and Geology Rep. 21. Reno, Nev.

Goldschmidt, V.M. 1954. Geochemistry. p. 730 Clarend on Press. Oxford, Eng.

Hill, W.L. 1964. Raw materials in superphosphate: Its history, chemistry and manufacture. 349 p. illus. U.S. Dep. Agr. and TVA.

Kubota, Joe. 1977. Molybdenum status of U.S. soils and plants. In: E. Chappell and K. Peterson (eds.) The Geochemistry, Cycling and Indus- trial Uses of Molybdenum. Vol. II. 555-581. Marcel Dekker, Inc., New York.

Kubota, Joe., V.A. Lazar, L.N. Langan, and K.C. Beeson. 1961. The relationship of soils to molybdenum toxicity in cattle in Nevada. Soil Sci. Soc. Amer. Proc. 25:227-232.

Levaggi, D.A., W. Oyung, and M. Feldstein. 1971. Microdetermination of fluoride in vegetation by oxygen bomb combustion and fuoride ion electrode analysis. J. Air Pollution Control Ass. 21:277-279.

National Academy of Sciences. (Committee on Biologic Effects of Atmospheric Pollutants). 1971. Fluorides. p. 295. Washington, D.C.

Nordstrom, D.K., and E.A. Jenne. 1977. Fluoride solubility equilibria in selected geothermal waters. Geochimica et Cosmochimica Acta 41:175188.

Underwood, E.J. 1971. Trace elements in human and animal nutrition. 3rd Ed. p. 543. Academic Press, N.Y. and London. 